\title{
Chemical composition of seeds of four Bulgarian grape varieties
}

\author{
Composição química das grainhas de quatro castas búlgaras
}

\author{
Temenuzhka Ovcharova ${ }^{1}$, M. Zlatanov ${ }^{1 *}$, R. Dimitrova ${ }^{2}$
}

\author{
${ }^{1}$ Department of Chemical Technology, University of Plovdiv "Paisii Hilendarski”, 24 Tzar Assen Str.,4000 Plovdiv, Bulgaria. \\ ${ }^{2}$ Institute of Organic Chemistry with Centre of Phytochemistry, Bulgarian Academy of Science, 1113 Sofia, Bulgaria.
}

*corresponding author: Tel: +359 32 261269; +359 32261 277; e-mail: magzlat@uni-plovdiv.bg

(Received 21.01.2016. Accepted 02.06.2016)

\section{SUMMARY}

The composition of grape seeds from two white dessert ('Bolgar' and 'Super ran Bolgar') and two red wine Bulgarian varieties ('Mavroud' and 'Shiroka melnishka loza') was investigated. The content of proteins was established by Kjeldhal method and was found to be $6.3-8.9 \%$. The content of carbohydrates - calculated as the difference of mean values: 100 - (amount in percentage of oil, moisture, protein and ash) - was 65.5 $70.9 \%$. The content of oil - by extraction with n-hexane - was $11.6-16.5 \%$. The content of phospholipids was determined spectrophotometrically after isolation by chromatographic methods and was found to be $0.6-0.9 \%$, including phosphatidylcholine, phosphatidylinositol and phosphatidic acids. The sterol content determined by gas chromatography was $0.3-0.4 \%$ while $\beta$-sitosterol $(70.0-72.1 \%)$ and campesterol $(18.5-19.9 \%)$ were the major components. In the phospholipids and sterol esters, saturated and monounsaturated fatty acids presented higher amount than the triacylglycerols. Fatty acids of sterol esters and phospholipids were determined by gas chromatography after isolation. The quantity of palmitic acid in the phospholipid fraction was $43.4-59.4 \%$, the content of oleic acid was $9.0-14.0 \%$ and the content of linoleic acid was $10.0-24.5 \%$ while in the sterol esters, the predominant ones were mainly linoleic $(40.7-53.8 \%)$, oleic $(24.9-35.5 \%)$ and palmitic acids $(13.0-16.7 \%)$. Linoleic $(68.5-72.3 \%)$ and oleic acids $(16.3-18.7 \%)$ were found to be the main components of the triacylglycerols. The tocopherol content varied from $67.7 \mathrm{mg} \mathrm{kg}^{-1}$ to $290.5 \mathrm{mg} \mathrm{kg}^{-1}$ where $\alpha$-tocopherol $(74.8-84.4 \%)$ was the predominant component.

\section{RESUMO}

Foi estudada a composição das grainhas de duas castas brancas ('Bolgar' e 'Super ran Bolgar') e de duas castas tintas búlgaras ('Mavroud' e 'Shiroka melnishka loza'). O teor de proteínas foi determinado pelo método de Kjeldhal, estando compreendido entre 6.3 e $8.9 \%$. O teor de glúcidos - calculado como a diferença de valores médios: 100 - (teor em percentagem do óleo, humidade, proteína e cinzas) - foi de 65.5 - $70.9 \%$. O teor de óleo - extraído com n-hexano - foi de 11.6 - 16.5\%. A concentração de fosfolípidos foi determinada espectrofotometricamente após isolamento por métodos cromatográficos, sendo de $0.6-0.9 \%$, incluindo fosfatidilcolina, fosfatidilinositol e ácidos fosfatídicos. A fração dos esteróis, determinada por cromatografia gasosa, representou $0.3-0.4 \%$, sendo maioritariamente constituída por $\beta$-sitosterol (70.0 - $72.1 \%)$ e por campesterol (18.5 - 19.9\%). Nos fosfolípidos e ésteres de esteróis, os ácidos gordos saturados e monoinsaturados apresentaram preponderância relativamente aos triacilgliceróis. A análise dos ácidos gordos foi efetuada, após isolamento, por cromatografia gasosa. Na fração fosfolipídica, a quantidade de ácido palmítico variou entre 43.4 e $59.4 \%$, a de ácido oleico foi de $9.0-14.0 \%$ e a de ácido linoleico foi de 10.0 - $24.5 \%$. Já nos ésteres de esteróis, observou-se predominância do ácido linoleico (40.7 - 53.8\%), do ácido oleico (24.9 - 35.5\%) e do ácido palmítico (13.0 $16.7 \%)$. Verificou-se ainda que os ácidos linoleico $(68.5-72.3 \%)$ e oleico $(16.3-18.7 \%)$ constituíam os principais componentes dos triacilgliceróis. O teor de tocoferol variou entre $67.7 \mathrm{mg} \mathrm{kg}^{-1}$ e $290.5 \mathrm{mg} \mathrm{kg}^{-1}$, sendo preponderante o $\alpha$-tocoferol $(74.8-84.4 \%)$.

Key words: carbohydrates, grape seed oil, lipids, proteins.

Palavras-chave: glúcidos, óleo de grainha, lípidos, proteínas.

\section{INTRODUCTION}

Grape seeds comprise about $5 \%$ of the fruit weight (Choi and Lee, 2009) and more than 3 million tons of them are discarded annually worldwide (Fernandes et al., 2012) (in Bulgaria $10000-20000$ tons annually). They are an important part of the pomace, corresponding to $38-52 \%$ of dry matter (Maier et al., 2009). In fact, grape seeds are often referred as a significant agricultural and industrial waste (Luque-
Rodriguez et al., 2005; Freitas et al., 2008; Kim et al., 2008; Lutterodt et al., 2011), a by-product of winemaking containing significant amounts of oil, proteins, carbohydrates, among others.

Grape seed oil is used for salad dressings, marinades, deep frying, flavoured oils, baking, massage oil, sunburn repair lotion, hair products, body creams, lip balm and hand creams (Akin and Altindisli, 2011). It is a good source of polyunsaturated fatty acids (PUFAs), vitamins and antioxidants. For this reason it

This is an Open Access article distributed under the terms of the Creative Commons Attribution License (http://creativecommons.org/licenses/by/4.0), which permits unrestricted use, distribution, and reproduction in any medium, provided the original work is properly cited. 
is used for the prevention of a variety of diseases such as thrombosis, cardiovascular diseases, reduction of cholesterol in serum, dilation of blood vessels, cancer reduction and regulation of autonomic nerves (LuqueRodríguez et al., 2005; Yi et al., 2009).

The oil content of grape seeds varies between $8 \%$ and 20\% (Ohnishi et al., 1990; Schuster, 1992; Baydar and Akkurt, 2001; Schieber et al., 2002; LuqueRodriguez et al., 2005; Baydar et al., 2007; Martinello et al., 2007; Campos et al., 2008; Ahmadi and Siahsar, 2011; Canbay and Bardakçi, 2011; Sabir et al., 2012) depending on grape variety and agrocultural conditions.

Razuvaev (1980) found about $8-10 \%$ oil, $44-57 \%$ cellulose, $3.7 \%$ tannins and $1-2 \%$ mineral substances in grape seeds. Campos et al. (2008) reported that the grape seeds contain about $40 \%$ fibres, $11 \%$ proteins, $7 \%$ phenolic compounds, as well as sugar and minerals. According to Kamel et al. (1985), the seeds contain $8.2 \%$ crude proteins. Mironeasa et al. (2010) reported $28 \%$ cellulose, 4 $6 \%$ tannins, $10-25 \%$ oil, and $2-4 \%$ minerals. Licev et al. (1974) indicated about $10-11 \%$ cellulose, $4-$ $6 \%$ tannins, and $20 \%$ oil.

According to our knowledge, phospholipid composition and fatty acid profile of phospholipids were not investigated.

The total sterols in grape seed oil were found in considerably small amounts $(0.27 \%)$ and sterol fraction included: $10.3-10.6 \%$ campesterol, $9.2-$ 13.7\% stigmasterol, 73.9 - 74.9\% $\beta$-sitosterol (Fedeli et al. 1966; El-Shami et al. 1999; Madawala et al., 2012). Cholesterol was not detected. There is no information about the ratio between free and esterified sterols, nor about fatty acid composition of the sterol esters.

Triacylglycerols (TAGs) are complex molecules present in all oils and fats. They serve mainly as energy stores, but are also employed as carriers of fatty acids within aqueous solutions such as blood. Linoleic and oleic acids predominate in the grape seed oil (Akhter et al. 2006; Ramos et al., 2009). Data about triacylglycerol structure were reported by Tuberso et al. (2007). LLP, LLO, and LLL (L linoleic acid, $\mathrm{O}$ - oleic acid and $\mathrm{P}$ - palmitic acid) were found to be the major components. According to Barron et al. (1988) and Bail et al. (2008), the content of LLL (35.8\% and $34.9-$ $41.8 \%$, respectively) is higher than the value (20.7\%) reported by Tuberso et al. (2007). They also reported higher amounts of other TAG species such as LPL, LOP, LOL and LSL.
The amount of tocopherols in grape seed oil ranged between 153.1 and $260.5 \mathrm{mg} \mathrm{kg}^{-1}$ according to Sabir et al. (2012), and between 121 and $829 \mathrm{mg} \mathrm{kg}^{-1}$ according to Gliszczynska-Swiglo et al. (2007) in the results of different kinds of oils. Kraujalyte et al. (2011) and Sabir et al. (2012) reported the predominance of $\alpha$-tocopherol but $\alpha$-tocotrienol, $\gamma$ tocopherol and $\gamma$-tocotrienol were also detected.

The aim of the present study is to characterize the chemical composition of grape seeds, including proteins, carbohydrates, ash, the content and composition of biologically active substances such as phospholipids, sterols and tocopherols; as well as fatty acid profile of triacylglycerols, individual phospholipids and sterol esters of triacylglycerol fraction extracted from seeds of Bulgarian grape varieties with a view to estimate the values of the oil as functional food with therapeutical effect, salad oil and for preparing cosmetic products and the seeds for source of food supplements.

\section{MATERIAL AND METHODS}

\section{Reagents}

All reagents used were of analytical grade of purity.

\section{Samples}

Grape seeds were separated from fresh fruits of two white grape varieties - 'Bolgar' and 'Super ran Bolgar' - and of two red grape varieties - 'Mavroud' and 'Shiroka melnishka loza' (vintage 2013). They were provided by the Agricultural University, Faculty of Viticulture and Horticulture, Plovdiv, Plovdiv region in South Bulgaria. All grape seeds were subjected to air-drying $\left(20^{\circ} \mathrm{C}\right)$ before the analyses and then directly subjected to extraction. The moisture content was found to be in the range from $6.2 \%$ to $8.2 \%$ wt. All experiment repetitions were technical replicates.

\section{Oil extraction}

The dried grape seeds were ground by a grinder with knives just before extraction using Soxhlet apparatus with hexane for $8 \mathrm{~h}$ (ISO 659, 2009). Solvent recovery was made in rotary distillation unit and the remaining amount of the solvent was evaporated under a stream of nitrogen. The oil obtained was weighted and then the yield was calculated as a percentage in terms of dry weight and kept in stoppered bottles in the refrigerator.

\section{Determination of protein content}

Total proteins were determined by Kjeldhal method, according to ISO 20483 (2007), using VELP 
scientifica apparatus including DK 6b Heating digester, JP water aspirator and UDK 127 Distillation unit. The percentage of proteins was calculated using Factor 6.25.

\section{Determination of carbohydrate composition}

Carbohydrate content was calculated as follows (Besbes et al., 2004): Carbohydrate content (\%) $=100$ - (percentage of oil, water, protein, and ash content). The amount and composition of the soluble carbohydrates were determined by high performance liquid chromatography (HPLC) on a Agilent ${ }^{\circledR}$ LC 1220 (USA) instrument equipped with Zorbax Carbohydrate column $(150 \mathrm{~mm} \times 4.6 \mathrm{~mm}, 5 \mu \mathrm{m}$, Agilent) and ZorbaX Reliance Cartridge-guardcolumn (Agilent) and refractive index detector (RID 1260). The mobile phase was acetonitrile/water 80:20

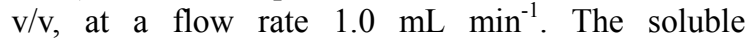
carbohydrates were identified by comparing their retention times with those of standards (individual pure mono- and disaccharides with purity $\geq 98 \%$ ).

\section{Determination of ash}

From defatted meal, $2 \mathrm{~g}$ of each sample were weighed and put in a crucible and then incinerated in an oven at $600{ }^{\circ} \mathrm{C}$ for $6 \mathrm{~h}$. The obtained ash was weighed (ISO 2171, 2009).

\section{Determination of fatty acid composition}

Separation of fatty acid fraction of triacylglycerols, individual phospholipids (phosphatidylcholine, phosphatidylethanolamine, phosphatidylinositol and phosphatidic acids) as well as sterol esters was performed using TLC. Briefly, the sample $(1 \mathrm{~mL}$ solution of phospholipid concentrate) was applied on $20 \mathrm{~cm} \times 20 \mathrm{~cm}$ glass plates with $0.2 \mathrm{~mm}$ Silica gel 60 $\mathrm{G}$ layer impregnated with $1 \%$ aqueous solution of $\left(\mathrm{NH}_{4}\right)_{2} \mathrm{SO}_{4}$. The plate was developed with chloroform: acetone: methanol: acetic acid: water 50:20:10:10:5 (by volume). The bands were visualised by iodine treatment, detected and scraped. After that the individual phospholipids were eluated by Folch reagent (chloroform: methanol 2:1 v/v). Sterol esters were isolated from the triacylglycerols also by TLC. Sample size of $2-2.5 \mathrm{~g}$ (precisely measured) was applied on several $20 \mathrm{~cm} \times 20 \mathrm{~cm}$ glass plates with $0.5 \mathrm{~mm}$ thick Silica gel $60 \mathrm{G}$ layer (Merck, Darmstadt, Germany) and developed with nhexane:diethyl ether:acetic acid $(80: 20: 1 \mathrm{v} / \mathrm{v} / \mathrm{v})$. The fatty acid composition of phospholipids, sterol esters and triacylglycerols was determined by GC of fatty acid methyl esters (FAME) (ISO 5508, 1990) after transmethylation at $50{ }^{\circ} \mathrm{C}$ with sulfuric acid in methanol as catalyst (Christie, 2003). Fatty acid methyl esters (FAME) were purified by TLC on $20 \times$ $20 \mathrm{~cm}$ plates covered with $0.2 \mathrm{~mm}$ Silica gel $60 \mathrm{G}$ layer (Merck, Darmstadt, Germany) with mobile phase n-hexane:diethyl ether 97:3 v/v. Gas chromatographic analysis was performed on a HP 5890 apparatus (Hewlett Packard $\mathrm{GmbH}$, Austria) equipped with FID, $60 \mathrm{~m} \times 0.25 \mathrm{~mm}$ capillary DB-23 column (Agilent Technologies, Santa Clara CA, USA). The column temperature was programmed from $130{ }^{\circ} \mathrm{C}(1 \mathrm{~min})$ to $170{ }^{\circ} \mathrm{C}$ at $6.5^{\circ} \mathrm{C} \mathrm{min}{ }^{-1}$; at $3{ }^{\circ} \mathrm{C}$ $\mathrm{min}^{-1}$ to $215^{\circ} \mathrm{C}(9 \mathrm{~min})$, at $40{ }^{\circ} \mathrm{C} \mathrm{min}^{-1}$ to $230{ }^{\circ} \mathrm{C}(1$ $\mathrm{min})$; injector and detector temperatures were $270{ }^{\circ} \mathrm{C}$ and $280{ }^{\circ} \mathrm{C}$, respectively. Hydrogen was the carrier gas at a flow rate of $0.8 \mathrm{~mL} \mathrm{~min}^{-1}$; split was 50:1. The identification of FAME was based on external standard mixtures (37 components standard mixture provided by Agilent Technology). Each of the experiments was repeated three times.

\section{Determination of triacylglycerol structure}

For the identification and quantification of TAG fraction, preliminary isolated by TLC (Christie, 2003) a $3 \mathrm{mg} \mathrm{mL} \mathrm{m}^{-1}$ solution in dichloroethane by reserved phase high-performance liquid chromatography (RPHPLC) was used. The analysis was performed on Agilent 1100 system (Agilent Technologies, USA) equipped with a Rheodyne injector (7725i Rheodyne, USA) and evaporative light-scattering detector (ELSD, PL-ELS 1000 Polymer Laboratories Inc., Amherst MA, USA) programmed at evaporator temperature of $82{ }^{\circ} \mathrm{C}$ and air pressure of $1.2 \mathrm{~atm}$. A ChemStation Rev.B.04.03 (Agilent Technologies, USA) software was used. Separation was performed with $250 \times 4.6 \mathrm{~mm}$ Inertsil 5 ODS-2 column (Varian Inc., Palo Alto CA, USA). A $150 \mathrm{~min}$ step-wise gradient was applied at a flow rate of $1 \mathrm{~mL} \mathrm{~min}^{-1}$ with mobile phase of: A - dichloromethane, B acetonitrile, $\mathrm{C}$ - iso-propanol and a gradient program as follows: from $10 \% \mathrm{~A}$ : $80 \% \mathrm{~B}$ : $10 \% \mathrm{C}$ to $17 \% \mathrm{~A}$ : $83 \% \mathrm{~B}: 10 \% \mathrm{C}$ over $40 \mathrm{~min}$, kept at this for $20 \mathrm{~min}$ and changed to $35 \% \mathrm{~A}: 55 \% \mathrm{~B}: 10 \% \mathrm{C}$ over $90 \mathrm{~min}$. The column temperature was thermostated at $30{ }^{\circ} \mathrm{C}$ (Agilent 1100 Series G1316A compartment). TAG species in the sample were determined by spikes of authentic standard TAG separated previously in laboratory conditions from natural plant vegetable oils by silver ion TLC (Ag-TLC). The standards were identified by their fatty acid composition. The component molecular TAG varieties (if any) were fixed by RP-HPLC under the same experimental conditions. The size of each peak was estimated according to the relative content of the target component in the sample. The quantification of TAG was done by precise calibration of the ELSD with monoacid standard TAG: LnLnLn, LLL, OOO, PPP, SSS (Ln - linolenic acid, L - linoleic acid, O - oleic acid, P - palmitic acid and S - stearic acid residues). The linear interval of detector response was 
determined (1.5 to $22 \mu \mathrm{g}$ TAG in $20 \mu \mathrm{L}$ ) and the respective linear equations were obtained. The TAG quantities were fixed respectively and the evaluated TAG fatty acid composition was compared with that determined directly by GC-FID.

\section{Determination of phospholipids}

The air-dried seeds were subjected to Folch extraction according to Christie (2003). After that phospholipids were recovered from triacylglycerols by hydration with $1.5-3.0 \%$ water by weight to oil at $76-82{ }^{\circ} \mathrm{C}$ (Pierce, 1996). The phospholipid classes were isolated by two-dimensional thin-layer chromatography (TLC) as follows: the sample (0.1 $\mathrm{mL}$ ) was poured out drop by drop on $20 \times 20 \mathrm{~cm}$ glass plates with $0.2 \mathrm{~mm}$ Silica gel $60 \mathrm{G}$ layer impregnated with $1 \%$ aqueous $\left(\mathrm{NH}_{4}\right)_{2} \mathrm{SO}_{4}$. In the first direction the plate was developed with chloroform:methanol:ammonia, 65:25:5 v/v/v and in the second - $\quad$ with chloroform:methanol:ammonia:acetic acid:water, 50:20:10:10:5 v/v/v (Zlatanov et al., 2009). The individual phospholipids were detected and identified by spraying with specific reagents according to Christie (2003): Dragendorff test (detection of choline-containing phospholipids); Ninhydrin spray (for phospholipids with free amino groups) and Shiff's reagent (for inositol containing phospholipids). Additional identification was performed by comparing the respective $\mathrm{R}_{\mathrm{f}}$ values with those of authentic commercial standards subjected to Silica gel $60 \mathrm{G}$ TLC under identical experimental conditions. The quantification was carried out spectrophotometrically against a standard curve by measuring the phosphorous content at $700 \mathrm{~nm}$ after scraping the respective phospholipid spot and mineralization of the substance with a mixture of perchloric acid: sulphuric acid, 1:1 v/v. The calibration curve was constructed by using a standard solution of $\mathrm{KH}_{2} \mathrm{PO}_{4}\left(1-130 \mu \mathrm{g} \mathrm{mL} \mathrm{L}^{-1}\right.$ as phosphorus $)$.

\section{Determination of sterols}

The oil (sample size of $5 \mathrm{~g}$, precisely measured) was hydrolyzed with $50 \mathrm{~mL} 2 \mathrm{~N}$ ethanolic $\mathrm{KOH}$ (Christie, 2003) for one hour. Then $50 \mathrm{~mL}$ of water was added and the unsaponifiable lipids were extracted five times with $30 \mathrm{~mL}$-hexane. The solvent was removed by rotary evaporator. Unsaponifiables were dried in an oven at $105{ }^{\circ} \mathrm{C}$ for $30 \mathrm{~min}$. Thereafter the sample was dissolved in chloroform and purified by TLC on $0.2 \mathrm{~mm}$ Silica gel $60 \mathrm{G}$ plates impregnated with $0.2 \mathrm{~N}$ $\mathrm{NaOH}$, mobile phase $n$-hexane: diethyl ether (1:1). Then sterol composition was determined by gas chromatography with HP 5890 (Hewlett Packard $\mathrm{GmbH}$, Austria) Data Apex Clarity $^{\mathrm{TM}}$ chromatography station for Windows ${ }^{\mathrm{TM}}$ (Data Apex
Ltd 2006) equipped with $30 \mathrm{~m} \times 0.25 \mathrm{~mm}$ DB-5 column (Agilent Technologies, Santa Clara CA, USA) and flame ionization detector (FID). The temperature gradient ranged from $90{ }^{\circ} \mathrm{C}(2 \mathrm{~min})$ to $290{ }^{\circ} \mathrm{C}(15 \mathrm{~min})$ and then increased to $310{ }^{\circ} \mathrm{C}$ at $4{ }^{\circ} \mathrm{C}$ $\mathrm{min}^{-1}$ (hold $10 \mathrm{~min}$ ). The injector and detector temperatures were $300^{\circ} \mathrm{C}$ and $320^{\circ} \mathrm{C}$. Hydrogen was used as a carrier gas at $0.8 \mathrm{~mL} \mathrm{~min}^{-1}$ velocity, split $50: 1$. Identification was confirmed by comparison of retention times with those of a standard mixture of sterols (Zlatanov et al., 2009).

\section{Determination of tocopherols}

The total tocopherol content and individual composition were analyzed directly in the oil with a HPLC (ISO 9936, 2006) on a Merck-Hitachi unit (Merck, Darmstadt, Germany) equipped with a $250 \times$ $4 \mathrm{~mm}$ Nucleosil Si 50 - 5 column (Macherey-Nagel, Germany) and fluorescent detector (Merck-Hitachi F 1000). The operating conditions were as follows: mobile phase $\mathrm{n}$-hexane:dioxane $(96: 4 \mathrm{v} / \mathrm{v})$, excitation $295 \mathrm{~nm}$, emission $330 \mathrm{~nm}$, flow rate of $1 \mathrm{~mL} \mathrm{~min}^{-1}$. The peaks were identified by comparing the retention times for the oil samples and pure standard solutions of tocopherols and tocotrienols (Merck Darmstadt, Germany) of known concentration of them. The amount of tocopherols in the oil was calculated as the sum of tocopherol components and the total content was expressed in $\mathrm{mg} \mathrm{kg}^{-1}$.

\section{Statistical analysis}

The statistical analysis was performed by using the statistical function of Microsoft Office Excel. For each sample, three determinations have been done. The data were presented as average \pm standard deviation (SD).

\section{RESULTS AND DISCUSSION}

The general chemical composition of the tested seeds is shown in Table I. The investigated grape seeds contained relatively low amounts of oil in comparison with other vegetable oils. The highest oil content $(16.5 \%)$ was found to be in 'Super ran Bolgar' seeds. These amounts were similar to data reported early by Karimian et al. (2012) but lower than the percentages established by Razuvaev (1980). The moisture content ranged between $6.2 \%$ and $8.2 \%$. The seeds of red wine varieties - 'Mavroud'and 'Shiroka melnishka loza' - contain higher levels of proteins $(8.9 \%)$ than the seeds of white cultivars $(6.3-6.9 \%)$. For all tested varieties the amounts of carbohydrates varies in relatively narrow limits $(65.5-70.9 \%)$. The main part of them was insoluble carbohydrates $(59.2$ - $67.3 \%$ ) while a higher amount was detected in 
'Bolgar'. These data were similar to the results reported earlier by Kamel et al. (1985) and Mironeasa et al. (2010) but higher than the percentages for other Bulgarian cultivars found by Licev et al. (1974) as well as by Razuvaev (1980) which reported significantly lower quantities of carbohydrates (44.0 $57.0 \%)$.

Table I

General composition of grape seeds*

Composição geral das grainhas

\begin{tabular}{lcccc}
\hline & \multicolumn{4}{c}{ Varieties } \\
\cline { 2 - 5 } $\begin{array}{l}\text { Compounds } \\
\text { dw, \% }\end{array}$ & \multicolumn{3}{c}{ White varieties } & \multicolumn{2}{c}{ Red varieties } \\
& Bolgar & $\begin{array}{c}\text { Super ran } \\
\text { Bolgar }\end{array}$ & Mavroud & $\begin{array}{c}\text { Shiroka } \\
\text { melnishka } \\
\text { loza }\end{array}$ \\
\hline Oil content & $11.6 \pm 0.2$ & $16.5 \pm 0.7$ & $15.7 \pm 0.5$ & $13.9 \pm 0.3$ \\
Moisture & $8.2 \pm 0.2$ & $6.5 \pm 0.3$ & $7.8 \pm 0.3$ & $6.2 \pm 0.2$ \\
Proteins & $6.9 \pm 0.3$ & $6.3 \pm 0.1$ & $8.9 \pm 0.4$ & $8.9 \pm 0.4$ \\
Ash & $2.4 \pm 0.1$ & $2.5 \pm 0.1$ & $2.1 \pm 0.1$ & $2.8 \pm 0.1$ \\
Carbohydrates & $3.6 \pm 0.1$ & $5.1 \pm 0.2$ & $6.3 \pm 0.3$ & $4.2 \pm 0.2$ \\
\multicolumn{1}{c}{ insoluble } & $67.3 \pm 2.7$ & $63.1 \pm 1.9$ & $59.2 \pm 1.2$ & $64.0 \pm 2.6$ \\
\multicolumn{1}{c}{ soluble } & $3.6 \pm 0.1$ & $5.1 \pm 0.2$ & $6.3 \pm 0.3$ & $4.2 \pm 0.2$ \\
\hline *Means \pm SD 0 f three determinations. &
\end{tabular}

*Means \pm SD of three determinations.

Individual composition of soluble carbohydrates was presented in Table II. In the fraction of soluble carbohydrates the major part is disaccharides (47.7 $72.6 \%$ ). Higher quantities of them were detected in the seeds of 'Super ran Bolgar' and 'Shiroka melnishka loza'. Highest percentages of monosaccharides were found in the seeds of 'Mavroud' (42.2\%) at the expense of the lower content of trisaccharides (10.1\%). Glucose, galactose and fructose were the predominant components in all monosaccharide fractions while iso-maltose is the main constituent in trisaccharide fractions (more than 43.6.1\%) in all varieties. The content of trisaccharides varies; in white varieties their level was found to be considerably higher. The observed individual profile of soluble carbohydrates is different to the data reported by Rondeau et al. (2013) for grape pomace. Significantly higher quantities of fructose and galactose $(18.7 \%$ and $30.0 \%$ respectively $\mathrm{v} / \mathrm{s} \quad 0.6 \%$ and $3.9 \%$ respectively) were observed in pomaces by Rondeau et al. (2013), at the expense of lower values of glucose and xylose $(44.5 \%$ and $2.7 \% \mathrm{v} / \mathrm{s} \quad 65.5 \%$ and $13.9 \%$, respectively).

Table II

Composition of soluble saccharides*

Composição em glúcidos solúveis

\begin{tabular}{lcccc}
\hline Saccharides, \% & Bolgar & $\begin{array}{c}\text { Super ran } \\
\text { Bolgar }\end{array}$ & Mavroud & $\begin{array}{c}\text { Shiroka } \\
\text { melnishka } \\
\text { loza }\end{array}$ \\
\hline $\begin{array}{l}\text { Monosaccharides, } \\
\text { \% wt }\end{array}$ & $\mathbf{2 4 . 3 \pm \mathbf { 1 . 0 }}$ & $\mathbf{1 3 . 5} \pm \mathbf{0 . 5}$ & $\mathbf{4 2 . 2} \pm \mathbf{1 . 7}$ & $\mathbf{2 1 . 1} \pm \mathbf{0 . 4}$ \\
Fructose & $3.9 \pm 0.1$ & $4.6 \pm 0.1$ & $7.9 \pm 0.2$ & $4.2 \pm 0.2$ \\
Glucose & $9.9 \pm 0.3$ & $5.9 \pm 0.2$ & $18.7 \pm 0.7$ & $8.1 \pm 0.2$ \\
Galactose & $9.5 \pm 0.2$ & $2.4 \pm 0.1$ & $13.0 \pm 0.3$ & $5.8 \pm 0.2$ \\
Xylose & $0.6 \pm 0.02$ & $0.3 \pm 0$ & $1.1 \pm 0$ & $0.7 \pm 0.02$ \\
Rhamnose & $0.3 \pm 0$ & $0.4 \pm 0.02$ & $1.3 \pm 0$ & $2.3 \pm 0.1$ \\
Arabinose & $0.1 \pm 0$ & - & $0.2 \pm 0$ & - \\
\hline Disaccharides, & $\mathbf{5 6 . 5}$ \% wt & $\mathbf{7 0 . 2} \pm \mathbf{2 . 8}$ & $\mathbf{4 7 . 7} \pm \mathbf{1 . 4}$ & $\mathbf{7 2 . 6} \pm \mathbf{2 . 9}$ \\
Saccharose & $4.7 \pm 0.1$ & $3.4 \pm 0.1$ & $2.6 \pm 0.1$ & $5.7 \pm 0.2$ \\
Maltose & $2.1 \pm 0.1$ & $2.1 \pm 0.1$ & $1.1 \pm 0$ & $2.6 \pm 0.1$ \\
Iso-maltose & $49.7 \pm 2.0$ & $57.6 \pm 1.7$ & $43.6 \pm 1.3$ & $62.1 \pm 2.5$ \\
Other disaccharides & - & $7.0 \pm 0.2$ & $0.8 \pm 0$ & $2.2 \pm 0.1$ \\
\hline Trisaccharides, & $\mathbf{1 9 . 2} \pm \mathbf{0 . 8}$ & $\mathbf{1 6 . 3} \pm \mathbf{0 . 7}$ & $\mathbf{1 0 . 1} \pm \mathbf{0 . 4}$ & $\mathbf{6 . 3} \pm \mathbf{0 . 3}$ \\
$\quad$ \% wt & & & & \\
\hline
\end{tabular}

*Means \pm SD of three determinations.

General characteristic of oils are given in Table III. The sterol content in the oils was found to be similar to the data reported earlier by Madawala et al. (2012) and Piironen et al. (2003). The main part of sterol fraction was presented in free form (more than $97.0 \%$ ) like in other vegetable oils such as sunflower (Zlatanov et al., 2009) and lalemantia (Lallemantia iberica) (Zlatanov et al., 2012). Tocopherol content ranges in relatively large limits from $67.7 \mathrm{mg} \mathrm{kg}^{-1}$ in the oil of 'Super ran Bolgar' to $290.5 \mathrm{mg} \mathrm{kg}^{-1}$ in the oils of other grape varieties. The tocopherol level in 'Bolgar', 'Shiroka melnishka loza' and 'Mavroud' were similar to the quantities reported by Sabir et al. (2012).

Table III

Content of biologically active substances in the oils *

Teores de substâncias bioativas presentes nos óleos

\begin{tabular}{lccccc}
\hline \multicolumn{1}{c}{ Variety } & $\begin{array}{c}\text { Phospholipids, } \\
\text { \% wt. }\end{array}$ & $\begin{array}{c}\text { Total Sterol } \\
\text { fraction, \% }\end{array}$ & $\begin{array}{c}\text { Free sterols, } \\
\%\end{array}$ & $\begin{array}{c}\text { Esterified } \\
\text { sterols, \% }\end{array}$ & $\begin{array}{c}\text { Tocopherols, } \\
\mathrm{mg} / \mathrm{kg}\end{array}$ \\
\hline Bolgar & $0.8 \pm 0.03$ & $0.4 \pm 0.02$ & $94.3 \pm 1.9$ & $5.7 \pm 0.2$ & $269.5 \pm 5.4$ \\
Super ran Bolgar & $0.6 \pm 0.02$ & $0.3 \pm 0.01$ & $93.4 \pm 2.8$ & $6.6 \pm 0.2$ & $67.7 \pm 2.7$ \\
Mavroud & $0.9 \pm 0.04$ & $0.3 \pm 0.01$ & $93.5 \pm 1.9$ & $6.5 \pm 0.1$ & $156.3 \pm 4.7$ \\
Shiroka melnishka loza & $0.9 \pm 0.04$ & $0.3 \pm 0.01$ & $97.0 \pm 3.9$ & $3.0 \pm 0.1$ & $290.5 \pm 5.8$ \\
\hline
\end{tabular}

$*$ Means \pm SD of three determinations. 
The fatty acid composition of the four grape varieties is listed in Table IV. Fourteen fatty acids were identified in the triacylglycerols. The qualitative and quantitative profiles of all samples are comparable. Linoleic acid $(68.5-72.3 \%)$ predominates in the TAG followed by oleic $(16.3-18.7 \%)$ and palmitic acid $(8.8-11.5 \%)$. The content of stearic acid was found to be a very small percentage in comparison with other oils where it is about $3-5 \%$ (Gunstone, 2003). The other fatty acids were detected in negligible quantities. These results are close to data reported earlier by other authors (Bail et al., 2008; Lutterodt et al., 2011). Fatty acid composition of grape seed oil is also similar to that of classic sunflower oil, where linoleic and oleic acids are the main components (Gunstone, 2003).

Table IV

Fatty acid composition of triacylglycerols* Composição dos triacilgliceróis em ácidos gordos

\begin{tabular}{|c|c|c|c|c|}
\hline $\begin{array}{c}\text { Fatty acids, } \\
\%\end{array}$ & Bolgar & $\begin{array}{c}\text { Super ran } \\
\text { Bolgar }\end{array}$ & Mavroud & $\begin{array}{c}\text { Shiroka } \\
\text { melnishka } \\
\text { loza }\end{array}$ \\
\hline Lauric $\left(\mathrm{C}_{12: 0}\right)$ & $0.4 \pm 0.02$ & n.d. & $0.4 \pm 0.01$ & n.d. \\
\hline Myristic $\left(\mathrm{C}_{14: 0}\right)$ & $0.1 \pm 0$ & $0.1 \pm 0$ & $0.1 \pm 0$ & $0.1 \pm 0$ \\
\hline $\begin{array}{l}\text { Myristoleic } \\
\left(\mathrm{C}_{14: 1}\right)\end{array}$ & tr. & n.d. & tr. & $0.1 \pm 0$ \\
\hline $\begin{array}{l}\text { Pentadecanoic } \\
\left(\mathrm{C}_{15: 0}\right)\end{array}$ & n.d. & $0.1 \pm 0$ & $0.1 \pm 0$ & tr. \\
\hline Palmitic $\left(\mathrm{C}_{16: 0}\right)$ & $11.5 \pm 0.2$ & $8.8 \pm 0.3$ & $8.8 \pm 0.4$ & $10.0 \pm 0.3$ \\
\hline $\begin{array}{l}\text { Palmitoleic } \\
\left(\mathrm{C}_{16: 1}\right)\end{array}$ & $0.2 \pm 0.01$ & $0.1 \pm 0.01$ & $0.2 \pm 0.01$ & $0.3 \pm 0.01$ \\
\hline $\begin{array}{l}\text { Margarinic } \\
\left(C_{17: 0}\right)\end{array}$ & $0.1 \pm 0$ & $0.1 \pm 0$ & $0.1 \pm 0.01$ & $0.1 \pm 0.01$ \\
\hline Stearic $\left(\mathrm{C}_{18: 0}\right)$ & $1.0 \pm 0.03$ & $0.8 \pm 0.03$ & $1.0 \pm 0.04$ & $0.7 \pm 0.03$ \\
\hline Oleic $\left(\mathrm{C}_{18: 1}\right)$ & $17.6 \pm 0.7$ & $17.3 \pm 0.4$ & $18.7 \pm 0.7$ & $16.3 \pm 0.7$ \\
\hline Linoleic $\left(\mathrm{C}_{18: 2}\right)$ & $68.5 \pm 1.4$ & $72.2 \pm 2.9$ & $70.1 \pm 2.1$ & $71.3 \pm 2.9$ \\
\hline $\begin{array}{l}\text { Linolenic } \\
\left(\mathrm{C}_{18: 3}\right)\end{array}$ & $0.3 \pm 0.01$ & n.d. & $0.2 \pm 0.01$ & $0.5 \pm 0.02$ \\
\hline $\begin{array}{l}\text { Arachidic } \\
\left(\mathrm{C}_{20: 0}\right)\end{array}$ & $0.2 \pm 0.01$ & $0.1 \pm 0$ & $0.1 \pm 0$ & $0.2 \pm 0.01$ \\
\hline Gadoleic $\left(\mathrm{C}_{20: 1}\right)$ & $0.1 \pm 0$ & $0.1 \pm 0$ & $0.1 \pm 0$ & $0.3 \pm 0.01$ \\
\hline Behenic $\left(\mathrm{C}_{22: 0}\right)$ & n.d. & $0.3 \pm 0.01$ & $0.1 \pm 0.01$ & $0.1 \pm 0$ \\
\hline
\end{tabular}

The fatty acid composition of the four grape varieties is listed in Table IV. Fourteen fatty acids were identified in the triacylglycerols. The qualitative and quantitative profiles of all samples are comparable. Linoleic acid $(68.5-72.3 \%)$ predominates in the TAG followed by oleic $(16.3-18.7 \%)$ and palmitic acid $(8.8-11.5 \%)$. The content of stearic acid was found to be a very small percentage in comparison with other oils where it is about $3-5 \%$ (Gunstone, 2003). The other fatty acids were detected in negligible quantities. These results are close to data reported earlier by other authors (Bail et al., 2008; Lutterodt et al., 2011). Fatty acid composition of grape seed oil is also similar to that of classic sunflower oil, where linoleic and oleic acids are the main components (Gunstone, 2003).

The identification and quantification of TAG species indicated the presence of ten triacylglycerol structures (Table V). In the four tested varieties was found that the major component is LLL $(40.4-57 \%)$, followed by $\operatorname{LLO}(16.4-23.3 \%)$ and LLP $(8.4-15.4 \%)$. These results are different from those found in the literature (Tuberso et al., 2007). These authors reported that the content of LLP was the highest (35.1\%), followed by LLO (21.6\%) and LLL (20.7\%). The other six TAG species - LOO, LOP, LLS, OOO, OOP, LOS were presented in amounts ranging between $1.7 \%$ and $6.7 \%$ while the remaining type LPP was detected only in trace.

Table V

Triacylglycerol structure of grape seed oils* Estrutura dos triacilgliceróis dos óleos de grainha

\begin{tabular}{|c|c|c|c|c|c|}
\hline № & $\begin{array}{l}\text { TAG, } \\
\%\end{array}$ & Bolgar & $\begin{array}{l}\text { Super } \\
\text { ran } \\
\text { Bolgar }\end{array}$ & Mavroud & $\begin{array}{c}\text { Shiroka } \\
\text { melnishk } \\
\text { a loza }\end{array}$ \\
\hline 1 & LLL & $48.7 \pm 1.5$ & $40.4 \pm 1.6$ & $43.6 \pm 1.7$ & $57.0 \pm 2.3$ \\
\hline 2 & LLO & $18.5 \pm 0.7$ & $23.3 \pm 0.9$ & $23.2 \pm 0.5$ & $16.4 \pm 0.7$ \\
\hline 3 & LLP & $11.4 \pm 0.5$ & $15.4 \pm 0.6$ & $8.4 \pm 0.3$ & $10.1 \pm 0.4$ \\
\hline 4 & LOO & $3.4 \pm 0.1$ & $3.8 \pm 0.2$ & $5.2 \pm 0.2$ & $2.6 \pm 0.1$ \\
\hline 5 & LOP & $6.3 \pm 0.2$ & $6.7 \pm 0.3$ & $5.8 \pm 0.1$ & $4.5 \pm 0.1$ \\
\hline 6 & LLS & $4.3 \pm 0.2$ & $4.6 \pm 0.1$ & $4.7 \pm 0.1$ & $3.2 \pm 0.1$ \\
\hline 7 & LPP & tr. & tr. & tr. & tr. \\
\hline 8 & OOO & $2.2 \pm 0.1$ & $1.7 \pm 0.1$ & $3.0 \pm 0.1$ & $2.0 \pm 0.1$ \\
\hline 9 & OOP & $2.7 \pm 0.1$ & $2.3 \pm 0.1$ & $3.4 \pm 0.2$ & $2.1 \pm 0.04$ \\
\hline 10 & LOS & $2.5 \pm 0.1$ & $1.8 \pm 0.1$ & $2.7 \pm 0.1$ & $2.1 \pm 0.04$ \\
\hline
\end{tabular}

*Means \pm SD of three determinations.

The samples were also analysed to determine the individual composition of phospholipid fraction (Table VI). There is no information about the composition of phospholipids in grape seed oils for comparison but its qualitative profile was found to be close to that of other vegetable oils, such as sunflower and rape (Gunstone, 2007). Phospholipids include all classes typical for these oils. The major component was phosphatidylinositol (PI) (28.0 - 49.1\%), followed by phosphatidic acids (PA), phosphatidylcholine (PC) and phosphatidylethanolamine (PEA). The qualitative composition of the studied oils was found to be close but considerable differences were observed in the quantitative profile. The highest amount of PI was 
found in 'Super ran Bolgar' variety (49.1\%) at the expense of a lower quantity of PA while in other oils their content varied from $28.0 \%$ to $32.2 \%$. The variability of the PC and PEA was in more close limits. In comparison with other plant oils an unusual high content of PA was determined. This fact probably results from hydrolysis processes or unfinished stage of their biosynthesis in the oil. A relatively high level of sphingomyelin $(0.9-2.5 \%)$ was also observed while in other oils it was detected in insignificant amounts or in traces. This individual quantitative composition is different from the phospholipid profile of other vegetable oils such as sunflower, rape, corn oil where the PC and PI are the predominant components (Gunstone, 2003).

Table VI

Sterol composition of grape seed oil*

Esteróis do óleo de grainha

\begin{tabular}{lcccc}
\hline Sterols, \% & Bolgar & $\begin{array}{c}\text { Super } \\
\text { ran } \\
\text { Bolgar }\end{array}$ & Mavroud & $\begin{array}{c}\text { Shiroka } \\
\text { melnishka } \\
\text { loza }\end{array}$ \\
\hline Cholesterol & $\mathbf{0 . 8} \pm \mathbf{0 . 0 2}$ & $\mathbf{0 . 7} \pm \mathbf{0 . 0 2}$ & $\mathbf{0 . 6} \pm \mathbf{0 . 0 2}$ & $\mathbf{0 . 7} \pm \mathbf{0 . 0 2}$ \\
Brassicasterol & $2.6 \pm 0.1$ & $2.5 \pm 0.1$ & $2.3 \pm 0.1$ & $2.5 \pm 0.1$ \\
Campesterol & $19.9 \pm 1.0$ & $18.5 \pm 0.7$ & $19.6 \pm 0.6$ & $18.5 \pm 0.7$ \\
Stigmasterol & $3.4 \pm 0.1$ & $3.5 \pm 0.1$ & $3.5 \pm 0.1$ & $3.5 \pm 0.2$ \\
$\Delta^{7}$-Campesterol & $1.5 \pm 0.1$ & $1.1 \pm 0.1$ & $1.8 \pm 0.1$ & $1.1 \pm 0.1$ \\
$\beta$-Sitosterol & $70.0 \pm 1.4$ & $72.1 \pm 2.2$ & $70.4 \pm 2.1$ & $72.1 \pm 2.2$ \\
$\Delta^{5}$-Avenasterol & $0.5 \pm 0.02$ & $0.5 \pm 0.01$ & $0.6 \pm 0.02$ & $0.5 \pm 0.02$ \\
$\Delta^{7}$-Avenasterol & $0.8 \pm 0.03$ & $0.6 \pm 0.02$ & $0.6 \pm 0.02$ & $0.6 \pm 0.02$ \\
$\Delta^{7}$-Stigmasterol & $0.5 \pm 0.02$ & $0.5 \pm 0.03$ & $0.6 \pm 0.02$ & $0.5 \pm 0.02$ \\
\hline${ }^{*}$ -
\end{tabular}

*Means \pm SD of three determinations.

General sterol composition of the cultivars used for the investigations is given in Table VII. The obtained picture clearly shows that the qualitative and quantitative profile of all studied seeds is similar. $\beta$ Sitosterol $(70.0-72.1 \%)$ and campesterol (18.5 $19.9 \%$ ) were found to be the main components, followed by stigmasterol and brassicasterol. The values for campesterol and $\beta$-sitosterol are higher than the values of the Codex Alimentarius. These differences could be explained by different varieties, origin and agro-meteorological conditions. In contrast to earlier reports, the presence of cholesterol was established and its amount was found to be higher than in other vegetable oils where it was about $0.1-$ $0.2 \%$. The other sterol components $-\Delta^{7}$-campesterol, $\Delta^{5}$-avenasterol, $\Delta^{7}$-avenasterol, $\Delta^{7}$-stigmasterol were detected in negligible amounts in all investigated varieties of grape seed oils. These results are different to those reported by Fedeli et al. (1966) and El-Shami et al. (1999) that also noted the predominance of $\beta$ - sitosterol (73.8\%) in sterol fraction but different values of campesterol. A higher content of campesterol $(18.5-19.9 \%)$ was established at the expense of lower levels of stigmasterol $(3.4-3.5 \%)$ and $\Delta^{5}$-avenasterol $(0.5-0.6 \%)$ in comparison to the results reported by Madawala et al. (2012) and El Shami et al. (1999) who established $10.3 \%$ and $10.6 \%$ of campesterol, $9.2-13.7 \%$ stigmasterol and $5.1 \% \Delta^{5}$-avenasterol, respectively.

\section{Table VII}

Individual phospholipid composition in grape seed oil ${ }^{*}$ Composição fosfolipídica do óleo de grainha

\begin{tabular}{|c|c|c|c|c|}
\hline \multirow{3}{*}{ Phospholipids, \% } & \multicolumn{3}{|c|}{ Super } & \multirow{3}{*}{$\begin{array}{c}\text { Shiroka } \\
\text { melnishka } \\
\text { loza }\end{array}$} \\
\hline & Bolgar & ran & Mavroud & \\
\hline & & Bolgar & & \\
\hline Phosphatidylcholine & $16.0 \pm 0.5$ & $16.4 \pm 0.5$ & $23.8 \pm 1.0$ & $16.2 \pm 0.6$ \\
\hline Phosphatidylinositol & $28.0 \pm 0.6$ & $49.1 \pm 2.0$ & $33.9 \pm 1.4$ & $32.2 \pm 1.0$ \\
\hline $\begin{array}{l}\text { Phosphatidylethanol- } \\
\text { amine }\end{array}$ & $17.3 \pm 0.7$ & $13.1 \pm 0.5$ & $12.2 \pm 0.4$ & $10.3 \pm 0.4$ \\
\hline Phosphatidic acids & $25.3 \pm 0.5$ & $8.2 \pm 0.4$ & $14.1 \pm 0.6$ & $30.2 \pm 1.2$ \\
\hline Phosphatidylserine & $2.7 \pm 0.1$ & $2.6 \pm 0.1$ & $1.8 \pm 0.1$ & $2.2 \pm 0.1$ \\
\hline $\begin{array}{l}\text { Lysophosphatidylcho- } \\
\text { line }\end{array}$ & $1.6 \pm 0.1$ & $3.2 \pm 0.1$ & $4.2 \pm 0.2$ & $1.1 \pm 0.04$ \\
\hline $\begin{array}{l}\text { Lysophosphatidyletha- } \\
\text { nolamine }\end{array}$ & $1.4 \pm 0.1$ & $3.4 \pm 0.1$ & $2.6 \pm 0.1$ & $1.0 \pm 0.03$ \\
\hline Diphosphatidylglycerol & $2.7 \pm 0.1$ & $2.0 \pm 0.3$ & $3.7 \pm 0.1$ & $2.3 \pm 0.1$ \\
\hline $\begin{array}{l}\text { Monophosphatidylgly- } \\
\text { cerol }\end{array}$ & $2.8 \pm 0.1$ & $1.1 \pm 0.1$ & $1.2 \pm 0.1$ & $2.4 \pm 0.1$ \\
\hline Sphingomyelin & $2.2 \pm 0.1$ & $0.9 \pm 0.02$ & $2.5 \pm 0.1$ & $2.3 \pm 0.1$ \\
\hline
\end{tabular}

*Means \pm SD of three determinations.

The fatty acid profile of individual phospholipid classes is presented in Figure 1. The results show that the qualitative fatty acid composition of separate individual phospholipids is similar, but the quantitative profile is different. The content of palmitic acid was found to be the major component in all phospholipid classes $(37.9-68.0 \%)$, followed by oleic $(4.7-30.2 \%)$, stearic $(7.3-19.5 \%)$ and linoleic acid $(2.8-20.4 \%)$. The highest content of unsaturated fatty acids, mainly oleic and linoleic, was detected in PA $(6.9-30.2 \%)$ and PC $(6.4-25.9 \%)$ while in PI and PEA their amounts were relatively lower (2.8 $19.8 \%$ and $4.7-22.8 \%$ respectively). Identical fatty acids were detected in the fraction of sterol esters. The quantitative profile of the separate varieties is similar. Unsaturated acids, mainly linoleic, (40.7 $53.8 \%$ ) predominated, followed by oleic acid (24.9 $35.5 \%$ ). The content of saturated acids (mainly palmitic and stearic) is $13.0-16.7 \%$ and $4.2-6.7 \%$, respectively. Insignificant amounts of $\mathrm{C}_{12: 0}, \mathrm{C}_{14: 0}$, $\mathrm{C}_{15: 0}, \mathrm{C}_{17: 0}, \mathrm{C}_{20: 0}$ and $\mathrm{C}_{22: 0}$ were also detected. 


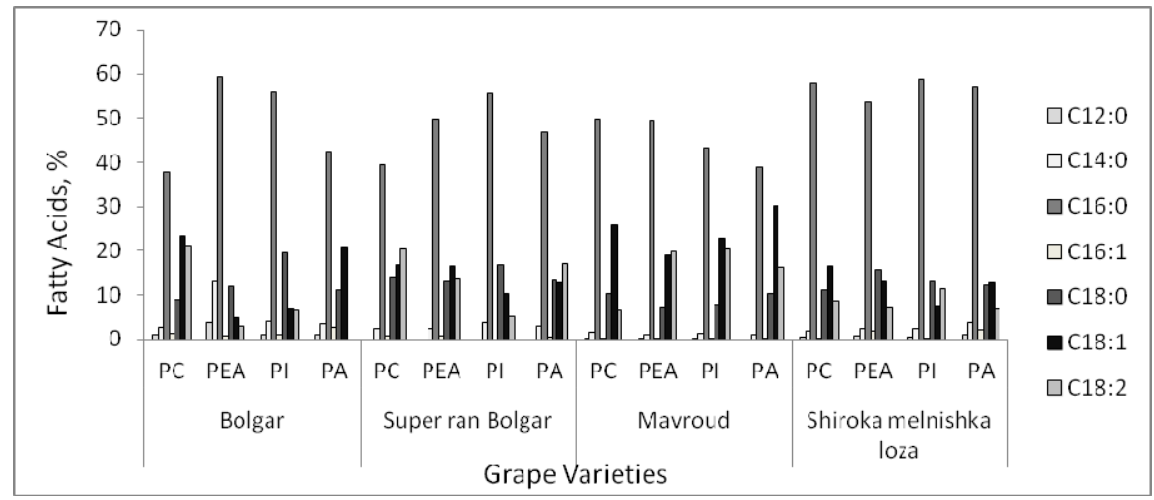

Figure 1. Fatty acid composition of individual phospholipids. PC - Phosphatidylcholine, PEA - Phosphatidylethanolamine, PI Phosphatidylinositol, PA - Phosphatidic acids.

Composição dos fosfolípidos em ácidos gordos. PC - Fosfatidilcolina, PEA - Fosfatidiletanolamina, PI - Fosfatidilinositol, PA- Ácidos fosfatídicos.

Figure 2 presents percentage of each group of fatty acids in each class of lipids. Phospholipids are presented with average value. The total content of saturated and MUFA in sterol esters is higher than in triacylglycerols at the expense of a lower level of
PUFA. On the other hand, the quantity of SFA in sterol esters was found to be significantly lower than in phospholipids where their content was more than $77.5 \%$.

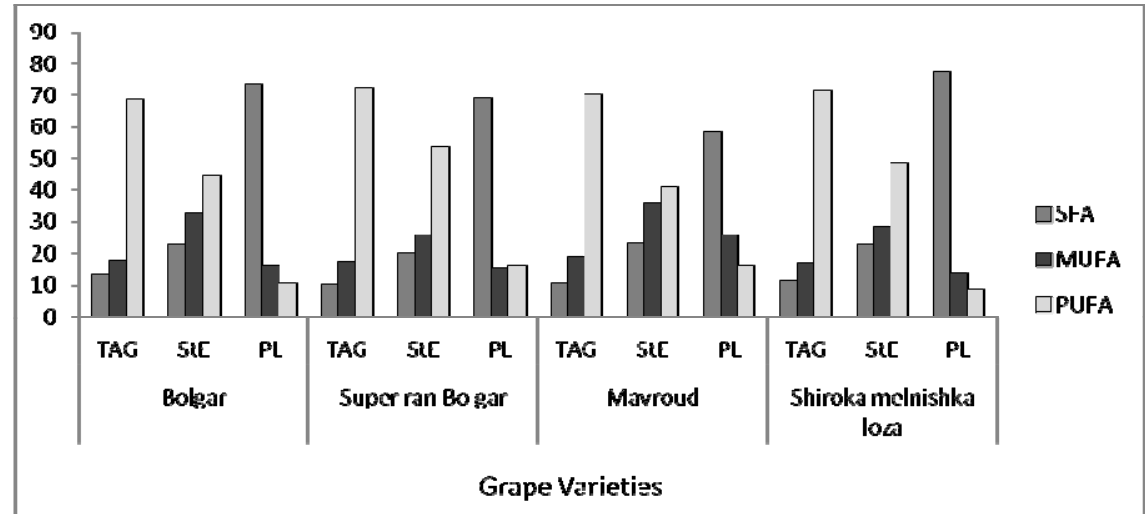

Figure 2. Distribution of fatty acid classes in triacylglycerols, sterols and phospholipids. TAG- triacylglycerols, StE- sterol esters, PLphospholipids, SFA- saturated fatty acids, MUFA- monounsaturated fatty acids, PUFA- polyunsaturated fatty acids.

Distribuição das classes de ácidos gordos nos triacilgliceróis, fosfolípidos e esteróis. TAG- triacilgliceróis, StE- ésteres de esteróis, PLfosfolípidos, SFA- ácidos gordos saturados, MUFA- ácidos gordos monoinsaturados, PUFA- ácidos gordos polinsaturados.

These differences can be due to the different stages of biosynthesis of the triacylglycerols, sterol esters and phospholipids. Phospholipids are synthesized at the first stage and are connected to SFA, which are synthesized at the same stage. Sterol esters are synthesized after that, and they connect with saturated and MUFA. Finally PUFA were synthesized and they were combined in TAG (Munshi et al., 1982).

The tocopherol composition of the oils is given in Table VIII. The qualitative and quantitative composition in all varieties was found to be similar. $\alpha$-Tocopherol $(74.8-84.4 \%)$ is the main component in tocopherol fraction, followed by $\gamma$-tocopherol (14.0 
- 23.3\%). These values are close to data reported earlier by Sabir et al. (2012) and Kraujalyte et al. (2011) who stated that $\alpha$-tocopherol was also predominated.

\section{Table VIII}

Individual tocopherols composition of grape seed oil* Tocoferóis do óleo de grainha

\begin{tabular}{lcccc}
\hline $\begin{array}{l}\text { Tocopherol, } \\
\mathrm{mg} / \mathrm{kg}\end{array}$ & Bolgar & $\begin{array}{c}\text { Super ran } \\
\text { bolgar }\end{array}$ & Mavroud & $\begin{array}{c}\text { Shiroka } \\
\text { melnishka } \\
\text { loza }\end{array}$ \\
\hline$\alpha$-tocopherol & $201.6 \pm 4.0$ & $45.8 \pm 1.4$ & $132.0 \pm 2.6$ & $231 \pm 4.6$ \\
$\gamma$-tocopherol & $37.7 \pm 1.1$ & $15.8 \pm 0.5$ & $24.4 \pm 0.7$ & $59.6 \pm 2.4$ \\
$\gamma$-tocotrienol & $30.2 \pm 1.2$ & tr. & tr. & tr. \\
\hline -Means &
\end{tabular}

\section{CONCLUSIONS}

The results obtained from detailed investigation on the grape seed composition show that the concentration of the seed components (oil, proteins, carbohydrates and ash) depends on the variety in relatively limited ranges. In the soluble carbohydrate

\section{REFERENCES}

Ahmadi S.M., Siahsar B.A., 2011. Analogy of physicochemical attributes of two grape seeds cultivars. Cienc. Investig. Agrar., 38, 291-301.

Akhter H., Hamid S., Bashir R., 2006. Variation in lipid composition and physic-chemical constituent among six cultivars of grape seed. J. Chem. Soc. Pak., 28, 97-100.

Akin A., Altindisli A., 2011. Determination of fatty acid composition and lipid content of some grape cultivar seeds in Turkey. BIBAD, 4, 13-15.

Bail S., Stuebiger G., Krist S., Unterweger H., Buchbauer G., 2008. Characterisation of various grape seed oils by volatile compounds, triacylglycerol composition, total phenols and antioxidant capacity. Food Chem., 108, 1122-1132.

Barron L.J.R., Celea M.V., Corzo N., 1988. Determination of triglyceride composition of grapes by HPLC. Chromatographia, 25, 609-612.

Baydar N.G., Akkurt M., 2001. Oil content and oil quality of some grape seeds. Turk. J. Agric. For., 25, 163-168;

Baydar N.G., Özkan G., Çetin E.S., 2007. Characterization of grape seed and pomace oil extracts. Grasas Aceites, 58, 29-33;

Besbes S., Blecker C., Deroanne C., Drira N., Attia H., 2004. Date seeds: chemical composition and characteristic profiles of the lipid fraction. Food Chem., 84, 577-584.

Campos L.M.A.S., Leimann F.V., Pedrosa R.C., Ferreira S.R.S., 2008. Free radical scavenging of grape pomace extracts from Cabernet Sauvingnon (Vitis vinifera). Bioresour. Technol., 99, 8413-8420.

Canbay H.S., Bardakçi B., 2011. Fatty acid, C, H, N and trace element composition in grape seed by GC/MS, FTIR, elemental fraction predominate disaccharides, mainly isomaltose, while in monosaccharides the major constituents were found to be galactose and glucose. Significant differences in oil content between white and red cultivar were not observed. The quantity and individual composition of biologically active substances in the oil of the separate varieties grape seeds (phospholipids, sterols and tocopherols) are identical but it differs from data of other regions probably as a result of different climatic conditions for cultivation of the plants. The triacylglycerols contains mainly PUFA, while in phospholipids and sterol esters SFA and MUFA predominate. The obtained information allows complete estimation of the seeds as a rich source of valuable food substances, mainly proteins and carbohydrates, of the quality of the grape seed oil as a food product as well as a source for preparing cosmetic products.

\section{ACKNOWLEDGMENTS}

The investigations were carried out with the partial financial support of contract SI 15 FC 001/2015 of the University of Plovdiv 'Paisii Hilendarski'.

analyzer and ICP/OES. SDU/Journal of Science (E-Journal), 6 , 140-148.

Choi Y., Lee J., 2009. Antioxidant and antiproliferative properties of a tocotrienol-rich fraction from grape seeds. Food Chem., 114, 1386-1390.

Christie W-W., 2003. Lipid Analysis. The Oily Press: Bridgwater, England.

El-Shami S.M., El-Mallah M.H., Mohamed S.S., 1999. Studies on the lipid constituents of grape seeds recovered from pomace resulting from white grape processing. Grasas Aceites, 43, 157160

Fedeli E., Lanzani A., Capella P. Jacini G. 1966. Triterpene alcohols and sterol of vegetable oils. JAOCS, 43, 254-256.

Fernandes L., Casal S., Cruz R., Pereira J.A., Ramalhosa E., 2013. Seed oils of ten traditional Portuguese grape varieties with interesting chemical and antioxidant properties. Food Res. Int., 50 161-166.

Freitas L.S., Jacques R.A., Richter M.F., Loviane da Silva A., Caramão E.B., 2008. Pressurized liquid extraction of vitamin $\mathrm{E}$ from Brazilian grape seed oil. J. Chromatogr. A, 1200, 80-83.

Gliszczynska-Swiglo A., Sikorska E., Khmelinskii I., Sikorski M., 2007. Tocopherol content in edible plant oils. Pol. J. Food Nutr. Sci., 57, 157-161.

Gunstone F.D., Harwood J.L. Dijkstra A.J., 2007. The Lipid Handbook. CRC Press: London and New York.

Gunstone F.D., Harwood J.L., Padley F.B. 2003. The Lipid Handbook. Chapman and Haal, London.

ISO 5508 1990. Animal and vegetable fat and oils. Determination of methyl esters of fatty acids- Gas chromatographic method. 
ISO 20483 2007. Cereals and pulses-Determination of nitrogen content and calculation of crude protein content- Kjeldhal method.

ISO 2171 2009. Cereals and pulses-Determination of ash yield by incineration.

ISO 659 2009. Oilseeds - determination of oil content (Reference method).

Kamel B.S., Dawson H., Kakuda Y., 1985. Characteristics and composition of melon and grape seed oils and cakes. JAOCS, 62, 881-883;

Karimian H., Nateghi L., Yousefi M., 2012. Comparison of seed oil characteristics between two type of Shahrodi grape (red and Fakhri). Adv. Environ. Biol., 6, 2126-2129;

Kim H., Kim S-G., Choi Y., Jeong H.S., Lee J., 2008. Changes in tocopherols, tocotrienols, and fatty acid contents in grape seed oils during oxidation. JAOCS, 85, 487-489;

Kraujalyte V., Andjelkovic M., Verhe R., Venskutonis P.R., 2011. Determination of volatiles, tocopherols and colour changes in aromatised oils with marjoram (Origanum majorana L.). Foodbalt, 84-89.

Licev V., Bojinov A., Dimov C., 1974. Investigation of lignine in grape seeds. Lozarstvo I vinarstvo, 5, 29-32;

Luque-Rodríguez J.M., Luque de Castro M.D., Pérez-Juan P., 2005. Extraction of fatty acids from grape seed by superheated hexane. Talanta, 68, 126-130;

Lutterodt H., Slavin M., Whent M., Turner E., Yu L., 2011. Fatty acid composition, oxidative stability, antioxidant and antiprliferative properties of selected cold-pressed grape seed oils and flours. Food Chem., 128, 391-399,

Madawala S.R.P., Kochhar S.P., Dutta P.C., 2012. Lipid components and oxidative status of selected speciality oils. Grasas Aceites, 63, 143-151.

Maier T., Schieber A., Kammerer D.R., Carle R., 2009. Residues of grape (Vitis vinifera L.) seed oil production as a valuable source of phenolic antioxidants. Food Chem., 112, 551-559;

Martinello M., Hecker G., Pramparo M.C., 2007. Grape seed oil deacidification by molecular distillation: Analysis of operative variables influence using the response surface methodology. $J$. Food Eng., 81, 60-64.

Mironeasa S., Leahu A., Codinã G.-G., Stroe S.-G., Mironeasa C., 2010. Grape seed: physico-chemical, structural characteristics and oil content. J. Agroaliment. Proc. Technol., 16, 1-6.
Munshi S.K., Sukhija S.P., Bahatia I.S., 1982. Lipids biosynthesis in developing kernels of almond (Prunus amygdalus Batsch). Phytochemistry, 22, 79-83.

Ohnishi M., Hirose S., Kawaguchi M., Ito S., Fujino Y., 1990. Chemical composition of lipids, especially triacylglycerol in grape seeds. Agric.Biol. Chem., 54, 1035-1042.

Pierce B., 1996. Sunflower oil. Guidance for refining, Tucson, Arizona.

Piironen V., Toivo J., Puupponen-Pimiä R., Lampi A-M., 2003. Plant sterols in vegetables, fruits and berries. J. Sci. Food Agr., 83, 330-337.

Ramos M.J., Fernandez C.M., Casas A., Rodriguez L., Perez A., 2009. Influence of fatty acid composition of raw materials on biodiesel properties. Bioresour. Technol., 100, 261-268.

Razuvaev N.I., 1980. Prelucrarea complexa a produselor secundare de la vinificatie, Bucuresti. Editura seres.

Rondeau P., Gambier F., Jolibert F., Brosse N., 2013. Compositions and chemical variability of grape pomaces from French vineyard. Ind. Crop. Prod., 43, 251-254.

Sabir A., Unver A., Kara Z., 2012. The fatty acid and tocopherol constituents of the seed oil extracted from 21 grape varieties (Vitis spp.). J. Sci. Food Agr., 92, 1982-1987.

Schieber A., Müller D., Rohrig G., Carle R., 2002. Influence of grape cultivar and processing method on the quality of cold-pressed grape seed oils. Mitt. Klosterneuburg, 52, 29-33.

Schuster W.H., 1992. Oelpflanzen in Europa. DLG-Verlag, Frankfurt am Main. 240 p.

Tuberso C.I.G., Kowalczyk A., Sarritzu E., Cabras P., 2007. Determination of antioxidant compounds and antioxidant activity in commercial oilseeds for food use. Food Chem., 103, 1497-1501.

Yi C., Shi J., Kramer J., Xue S., Jiang Y., Zhang M., Ma Y., Pohorly J., 2009. Fatty acid composition and phenolic antioxidants of winemaking pomace powder. Food Chem., 114, 570-576.

Zlatanov M.D., Angelova-Romova M.J., Antova G.A., Dimitrova R.D., Momchilova S.M., Nikolova-Damyanova B.M., 2009. Variations in Fatty acids, Phospholipids and Sterols during the Seed Development of high oleic sunflower variety. JAOCS, 86, 867-875.

Zlatanov M., Antova G., Angelova-Romova M., Momchilova S. Taneva S., Nikolova-Damyanova B., 2012. Lipid structure of Lallemantia seed oil: A potential source of Omega-3 and Omega-6 fatty acids for nutritional supplements. JAOCS, 89, 1393-1401. 